\title{
社会主義国に於ける自由化のディレンマ
}

过 村

明

\section{$\S$ まえがき}

テーマは与えられたものであるが, このテーマ にアプローチしていく場合，二つの側面を区別す る必要があるだろう。すなわち「自由化」を原因 とみる場合と，「自由化」を結果とみる場合との 二つである。1989 年末から東欧諸国に端を発 した「自由化」の波は, ソ連邦内部にも波及して いき，今やほとんどの社会主義諸国において「自 由化」は実現されつつある。つまり，「自由化」 が結果しつつあるわけで，そうした結果をうみだ してきた原因を探っていく立場は，「自由化」を 結果とみる立場だといっていいだろう。そしてこ うした「自由化」をもたらしたメカニスム，特に ディレンマといった矛盾を孕んだ弁証法的なメカ ニスムを探っていくのがそこでの課題となろう。

それに対して「自由化」を原因とみる立場は, 漸く実現した（結果した）「自由化」が，今後ど のような結果をうみだしていくか，特に矛盾を含 むような弁証法的なメカニスムとして，どのよう な過程を辿ることが予想されるか，どのような結 果に到達するのかを分析していくことが課題とな る。本報告においては，その両者をとりあげてい くが, 前者は過去の歴史に重点があり, 後者は未 来の予測に重点があるので, 主としては前者の方 に比重をおいて検討していくのが妥当であろう。

\section{$\S$ 近代化のディレンマ}

「近代化」（modernization）という概念に は, 実にさまざまな定義が含まれているが，筆者 はそれを「機械化」（mechanization）と 「民主化」の二つで考えている。 (1)詳しい検討は拙 著『大衆社会と社会主義社会』(1967) に譲る が, 「機械化」というのは，近代的な機械技術の 製品が普及していくことを意味する。一頃，「三
種の神器」といわれた電気洗濯機, 冷蔵庫, テレ ビなど，便利な機械が家庭生活に入っていくこと は「機械化」であり，「近代化」の一つの側面で ある。さらにはコンピューターやカセットテープ の普及，あるいはファックスやコードレス・テレ フォンの普及など, 次々と便利な機械，つまりは 「文明の利器」が普及していっているが, これら は便利で快適な近代生活を保障するもので, 「近 代化」の重要な側面を構成している。そして多く の「近代化」論は, この面を大きくとりあげてい る。しかし「近代化」はすべて「機械化」で説明 がつくものではない。たとえば，政党の「近代化」 といった場合には, 政党のなかに「文明の利器」 が普及していくことを意味するのではなく，その 政党のなかでの人間関係が「民主化」していくこ とを意味している。人事がボス交涉によって決定 されたり, 親分・子分の封建的な人間関係が支配 している政党であったならば,その政党はまだ「民 主化」しておらず,ひいては「近代化」していな いといわざるをえないのである。

では「機械化」と「民主化」との間には，どの ような関係があるのだろうか。全く無関係のもの なのか, 相関関係はあるものなのか, あるいは因 果関係があるものなのか。「機械化」は歴史的に は産業革命（１8 8 世紀末のイギリスに起こる）か ら，本格的に進展したものであるし，「民主化」 はフランス鞈 ( 同じく 18 世紀末のフランスに 起こる) から, 本格的に進展したものである。し かし「機械化」, つまり機械の発明とその発達は, 自然科学を基礎においているので, 逆戻りすると いうことがなく, 前進あるのみであるから, かな りオートマティックに進展していく。また機械の 導入は便利な「文明の利器」の導入であるから, どこででもそれを受容していく可能性が大きい。 つまり容易に普及していく性質をもっている。 
それに対して「民主化」のほうは，ひとびとの 意識の変革を土台としているので，そんなに簡単 には進展していかない。また一旦はある地域でそ れが実現したからといって，それが他の地域に波 及していくということも，機械の普及や技術移転 のように簡単なわけにはいかない。そこで「機械 化」と「民主化」との間には, 進展のテンポにス レが生まれ，「機械化」はかなり進展しているが, 「民主化」は一向に進まない，といったケースも 多くでてくる。そのために「機械化」と「民主化」 との間の関係についても，果して因果関係まであ るのか否か，あるいは全くの無関係なものである のかどうか，見方が違ってくるのである。

無関係だとみる立場では，たとえばナチス・ド イッや軍国主義時代の日本, および最近の「自由 化」が実現する以前の社会主義諸国の状態にその 根拠が求められる。六これらの国々では「文明の利 器」としての機械の普及はかなりの高度に達して いたにもかかわらず，一党独裁の政治体制がしか れ，「民主化」は実現していなかったわけである。 「機械化」と「民主化」とは別個の原理だとみる 立場においては，「近代化」は次のように図示す ことができよう。別個の原理であるから直交軸と

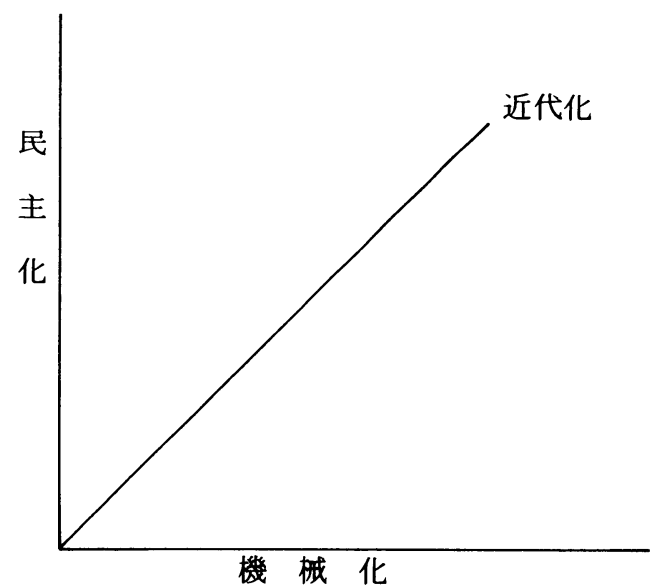

第 1 図「近代化」=「機械化」+「民主化」

して描くことができ，「近代化」はその両者の統 合として，対角線上に描くことができる。

これに対して，「機珹化」と「民主化」とは,
進展の度合いが違うので, 両者の間にタイム・ラ ッグはあるものの，「機械化」が進んでいけば, いずれは「民主化」も進んでいくと考える立場で ある。筆者は基本的にこのような立場をとってい るし，そのことをかなり早くから，次のような眓 式で表明してきた ${ }^{(3)}$ 。「機峨化」というのは基本

第 2 圀「政治」と「経済」とのズレ

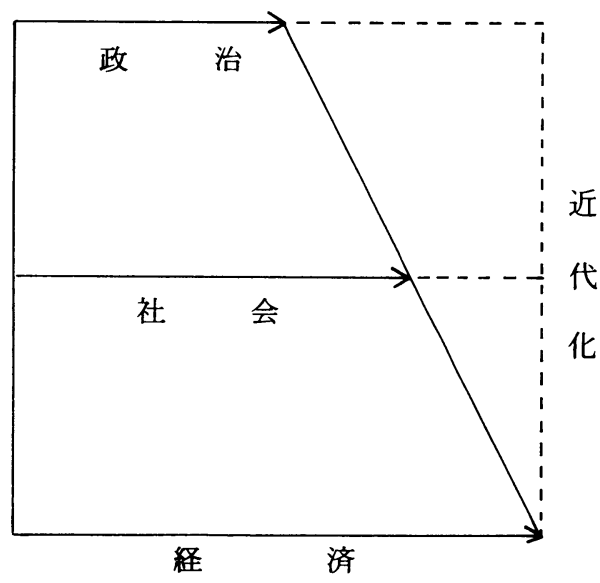

的に「経済」の発展によって実現していくもので あり゙，「民主化」というのは，「政治」の原理で あって, 両者は一見, 無関係のようにみえても, 中間に「社会」( 日常生活 )というものを媒介さ せることによって，時相のズレはあっても，因果 関係はあるものと考えるのである。第 2 図におい ては，「経済」を底辺 (つまり下部構造 )に設定 し，その近代化の度合，つまりは「機械化」の度 合が最も大きく進展すると考えて, 底辺の線分を 一番長く描いておく。その「経済」の発展をうけ て,「社会」という日常生活レベルでの近代化 （合理的なものの考え方や，便利で快適な生活を 欲する意識）もかなり進むと考えられるので, 「経 済」ほどの線分の長さではないが，かなりの長い 線で描くことができる。そして最後，「政治」の 近代化，つまりは「民主化」はそれほど簡単には 進展しないので, 線分は最も短かく描かれる。こ の図は，「経済」「社会」「政治」の三つのレベ ルでの近代化に，進展のズレがあることを表わし ていると同時に，進展が遅れる「社会」と「政治」 
の領域でも，「経済」の進展にひきずられて，「近 代化」の方向に向っていることをも表わしている。 図において，「政治」の近代化つまり「民主化」 は,「経済」の近代化つまり「機械化」の半分し か進展していない形に描かれている。このズレか らして,「機械化」と「民主化」とは無関係な別 の原理だと考えるか，つまりは原理的に質の違う ものと考えるか，あるいは現状においては大きな スレが認められるにしても，「民主化」も「機峨 化」の影響をうけて，いずれは近代化が実現して いくと考えるか，つまりは量的な違いにすぎない ものと考えるかによって, 前記のような二つの立 場にわかれてくるのである。筆者の立場が後者で あることは先述した通りであるが，これをもう一 つ別の困で説明してみよう ${ }^{(4)}$ 。

第 3 図がそれであるが，「経済」「社会」「政 治」を下から三つの円で描く。そして一番下の 「経済」の円と一番上の「政治」の円とは, 接し

\section{第 3 図「政治」と「経済」との関連}

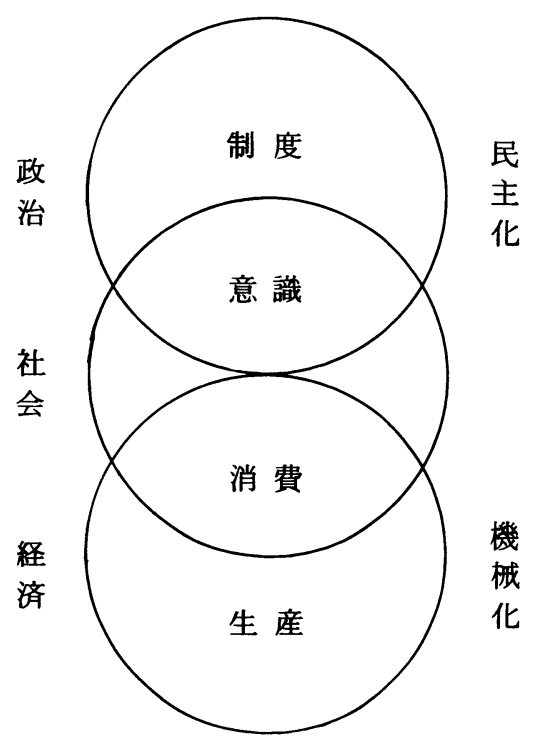

てはいるが交わってはいない。つまり「経済」と 「政治」とは一見無関係であることを表わしてい る。その一見無関俰にみえる二つの領域がどうし て因果関係を結んでくるのか, あるいはいいかえ れば，「経済」の領域に「機械化」という因子が
インプットされた場合，それがどうして「政治」 の領域において「民主化」というアウトプットと してでてくるのか, その手品の秘密を解く鍵は, 「社会」という円が両者に交わることによって, 下から徐々に上へと関連づけられていくことによ って理解される。

「経済」という領域が，基本的にいって物の「生 産」と「消費」とから構成されていることはいう までもない。機械技術の進展は，まず第一には 「生産」の領域で実現し, その結果, 大量生産が 可能となっていく。そして大量に生産された製品 には，単なる消費物資（衣類とか靴など）だけで はなく，耐久消費財といわれる機械の類いも含ま れており，それが人びとの日常生活に普及してい くのが「機械化」に他ならない。このようにして, 「機械化」（機械の導入）は「生産」の領域から 始まって「消費」の領域にまで浸透していく。

そうすると, 次の「社会」という円は, その「消 費」の領域を「経済」の円と共䡉しながら, 日常 生活の下部構造を形成し, そのうえに人びとの 「意識」という上部構造が組合わされていく。そ して人びとの「意識」も, 便利な「文明の利器」 に囲まれた「機械化」を土台としていると，その 便利性や能率性や快適性を損う勢力には反対する 傾向がでてくるであろう。要するに高度の快適な 日常生活を追求していくのが当然だという意識が 発達してくる。そして高度の快適な日常生活とい うなかには, 単なる物質的な豊かさだけでなく, 精神的な豊かさをも求めていくようになり, 結果 的には自由への欲求も芽生え, 民主主義が要望さ れていくであろう。

このような「意識」の領域が,「政治」という 円と共軛され，「政治」の領域における土台を形 成していく。そして最後,「政治」という円のな かでも「制度」の改革にまで至り，「民主化」が 実現していくものと考えられる ${ }^{(5)}$ 。

以上のように, 社会変動のメカニスムを「経済」 「社会」「政治」という三つの領域での絡み合い から考えていくと, 社会主義諸国における「自由 化」も当然の帰結であったことが理解されるであ ろう。要するに一党独裁制を採用してきた社会主 
義諸国も，資本主義諸国との競争に打ち勝つため には,「経済」の領域において「機械化」を推進 していかざるをえなかったわけで, その「機械化」 の推進がやがては「政治」の領域における「民主 化」をひき起すことになってしまったのである。 このメカニスムをもう少し詳しく, 特にティレン マといった弁証法的な発展に重点をおいてみてみ よう。

\section{$\S$ 社会主義の墓穴を掘るもの ${ }^{(6)}$}

マルクスは「資本主義の墓穴を掘るものは労働 者だ」といった。詳しく引用すれば,『共産党宣 言』のなかで次のようにいっている。「大工業が 発達するにつれて, フルジョアジーが生産をおこ ない, 生産物を取得する基礎そのものが, フルジ ヨアジーの足もとからとりさられる。フルジョア ジーはなによりもまず自分自身の墓掘人を生産す る。フルジョアジーの没落とプロレタリアートの 勝利とは,ともに避けられない」(7)

結局, フルジョアジーは生産の必要からプロレ タリアートを雇い入れていかなければならないが, プレタリアートが増殖すればするほど，互いに 団結して, フルジョアジーに反抗していき,やが てはフルジョアジーが打倒されるに至るというの である。資本家は自分に反抗してくる労働者を雇 い入れなければ, 生産そのものができない, とい ったティレンマを抱えていることになり，「資本 主義の墓穴を掘るものは労働者だ」という指摘は, 実に鋭い弁証法的論理だといってよい。

このような弁証法的論理は, 資本主義社会ない しはそれ以前の社会体制にのみ当てはまるもので はなく，社会主義社会にも妥当する。もちろんマ ルクスは，社会主義社会を資本主義社会の矛盾を 克服した理想的な社会として，未来に設定したも のであるから, 現実の社会としての社会主義社会 は知らなかったわけで, 社会主義社会の矛盾, あ るいはそこに貫徹する弁証法的論理の展開には触 れてはいない。しかし既にロシア革命以来, 現実 の社会主義社会も 70 年以上にわたって存在して きたのだから, 社会主義社会の現実的な運動法則 も分析して然るべきであるし，それをしないとい
うのは研究者の吝慢といわなければならないであ ろう。

そこで筆者の考えることは，「社会主義社会の 墓穴を掘るものはインテリだ」という法則である。 ロシア革命がおこなわれた 1917 年当時, ロシ アは人口の 8 割が農民という近代化の遅れた農業 国であった。そして新しく誕生した社会主義政権 は，周囲をとりまく資本主義諸国からの㔛威に対 抗していくためには, 経済的生産の面で, 飛矅的 な生産力の增強と生産性の向上とをはからなけれ ばならなかっただけでなく，古い慣習にとらわれ がちな人びとの意識の改造をもはからなければな らなかった。レーニンの悪戦苦闘の模様は, 次の ような述懐のうちによくあらわれている。

「革命がやってくるときでも，事は，人が一人 死んで, その死人が外にはこびだされるというぐ あいに，おこるものではない。旧社会が死滅する ときには，その死陔を棺に入れて釷を打ちつけ， 墓におさめるというぐあいにはいかない。この死 䠹はわれわれのあいだで分解し，腐敗し，われわ れ自身に病気を感染させる」(8)

確かに新しい社会の建設は, 何もない更地でお こなうわけのものではない。邪魔になる古い建物 (社会) の残䠹のなかで, それを片づけながら建 てていかなければならない。しかも社会の死は個 人の死とは違って, 死体を棺に納めて片づけると いうわけにはいかないのだから, 非常に厄介なこ とになる。新しい社会の建設は, 古い社会からの 惰性との闘い,および新しい理想の実現という二 重の闘いを強いられるのである。

特に旧社会からうけつがれた人びとの古い意識 は，そう簡単には変革することのできないものて あり, 新しい社会の建設にとって最大の障害物と なる。レーニンもそれを「習慣の力」との闘いと 名づけ, その苦東を吐露している。

「われわれが資本主義的機関・施設を投げすて たとき，資本主義をささえるもう一つの力がある ことがわかった—それは習慣の力である。….... うまくいけば機関・施設を一挙に粉砕することは できるが, どんなにうまくいっても, 習慣を一挙 に粉砕することはけっしてできない」 ${ }^{(9)}$ 
当時の一般大衆は，金銭勘定もできず，記帳す ることもできず，「不精，なげゃり，だらしなさ」 を特徵としていたのだから，そうした習慣の力, 惰性と闘うことは並大抵のことではなかったであ ろう。資本主義諸国に対抗して，近代的な国家や 近代的な企業を運営していくためには，学歴の高 い公務員や労働者を必要とする。そこで革命直後 には，革命前に育ったインテリを監視しながら利 用していく，という形をとらざるをえなかった。 しかし革命前に育ったインテリは, イデオロギー 的に全幅の信頼をおくわけにはいかないので，ソ ヴェト育ちのインテリを急速に養成していかなけ ればならなかった。それをおこなったのが，第 1 次 5 ケ年計画に連続する数度の 5 ケ年計画であっ た。

5 ケ年計画というと, 産業や経済の計画と考え られがちであるが, 大車輪での学校教育の発展も 含まれていたことを見過してはならない。たとえ ば第 1 次 5 ケ年計画の始まった 1928 年には, 大学数 (高等教育機関) は 129 , その学生数は 16 万 7000 人であったが，第 1 次計画の終る 頃 ( 1932 年) には, 大学数が 645 (約 5 倍)， その学生数が 39 万 4000 人 (約 2.5 倍) と増大 しているし，さらに技術学校数 (中等教育機関) では, 28 年に 1054 , その学生数は 20 万 8000 人だったのが， 32 年には学校数は 3096 (約 3 倍)，その学生数は 75 万 4000 人（約 3.6 倍） と激增しているのである。この増大傾向は第 2 次 5 ケ年計画の終る 1930 年代後半にも，そのま まひき継がれていて，いかに急激に一般大衆の高 学歴化あるいはインテリ化がはかられていったか を物語っている。

そうすると，インテリというのは，たとえ技術 系のものであっても，基本的には自由なものの考 え方，ひいては自由というものを要望していく性 格をもっている。これは一党独裁制を採用して, 思想の自由を統制していこうとする政治勢力にと っては，大変に厄介な存在である。ソ連当局のこ の苦本が，1938 年に刊行された『ソ連共産党 小史』に如実にあらわれている。この党史はイン テリ対策として刊行されたものであるし，それま
で労働者・農民に対する洗脳の方法として, 䪭動 者による小グループでの焗動集会 ( パーソナル・ コミュニケーション）が主流であったのが，イン テリ相手の小グルーブになると，どうしてもさま ざまな意見がでてくるので，それを抑制するうえ からも，煰動集会に代って印刷物（『党史』とい うテキスト)を一人で学習していく方法（マス・ コミュニケーション )にとって代られたのである。 結局, これはインテリの社会的役割の增大と, そ の反党的逸脱の可能性とのディレンマを解決すべ く案出された方策であった。

以上のような事実は，社会主義建設が進むこと 自体のうちに，それを妨害するような要因も肧胎 してくることを物語っている。こうして社会主義 社会についても，資本主義社会についてと同様の 弁証法的なメカニスムがみられるのであり，共産 主義をめざす独裁的政治指導が，その独裁に反抗 してくるようなインテリを，みずから増殖してい く必要に迫られているのである。だから「社会主 義社会の墓穴を掘るものはインテリだ」というこ とができるように思うのである。

\section{§「ねじれ」現象の解消}

社会心理学に整合性理論 ( cons i stency theory) とか均衡理論 ( balance theory) とかいわれるものがある。個人のレベルでいえば, 環境についての認識とか情報とかの間に矛盾があ った場合，それは心理的に不快であるから，その 不快な状態を解消しようとするヴェクトルが働き, 整合した状態とか均衡のとれた状態とかを回復す るというのである。たとえば非常にタバコの好き な人にとっては，「タバコをのむと肺癌になる」 という情報もしくは知識は，心理的に不快を与え る。なぜならば, タバコは吸いたいし，そうかと いって, 肺癌になって死ぬのもいやだから，まさ にディレンマに陥る。このような不快な状況を脱 出しようとして，さまざまの辻䘽合せ，あるいは 「いいわけ」が試みられる。たとえぱ，「タバコ をのむと肺癌になる」という知識はまだ $100 \%$ 証明されたものではないといって，情報そのもの の信恣性を否定していくのである。そうすれば一 
時的にせよ，心理的に不快な状態からは脱出する ことができる。あるいは，「タバコをのんで肺癌 で死ぬ人」の数よりも，交通事故で死ぬ人の数の ほうが多いではないかといって, 全く無関係なデ 一タをもってきて，心理的葛藤の苦しみを中和さ せようとする。以上は個人レベルでの心理的メカニ スムであるが, 同じようなメカニスムが社会現象 にも当てはまるのではなかろうか。今回の社会主 義諸国の自由化は，まさにそのことの証明となっ ている。

前記図式と同じように，「経済」「社会」「政 治」の三つの領域をわけて考えていくが，これら の領域の間に整合性が欠けると，その矛盾を解消 して, 均衡状態を求めようとするヴェクトルが㗢 くように思われる。それは第 4 図のように図示す ることができよう。「経済」の土台は，「後進」 段階から「先進」段階へと発展していくものと考

第 4 図社会的な均衡

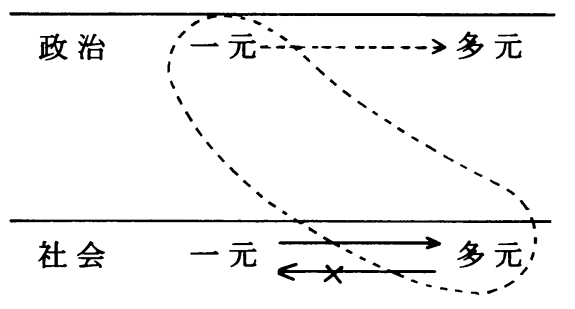

経済

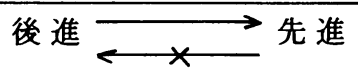

える。そして「経済」が「後進」段階にあるとき は, そのうえに乗っかる「社会」と「政治」は, まだ多様性がみられず，「一元」的な段階にある ものと考えられる。日常生活 (社会) においても, 消費物資はそんなに豊富にはなく，多様性にも欠 けているであろう。そのような段階では「政治」 も言論の自由や多様性もまだ出現せず, 独裁者に よる「一元」的な支配がおこなわれても，それな りに調和していて安定を保つものと考えられる。 ところが「経済」が「先進」段階へと発展してい
くと, 生産物も豊富になり,「社会」は多様性に 富んだ「多元」的なものになっていく。そしてそ れに呼応して，「政治」のレベルでも複数政党制 などの「多元」性が出現していき，三つのレベル がそれぞれに調和して，安定したシステムを構成 するようになっていく。結局, 縦にみて, 「後進 $\rightarrow$ 一元 $\rightarrow$ 一元」と対応するか, 「先進 $\rightarrow$ 多元 多元」と対応するかすれば，それぞれに安定し， 均衡を保つものといえる。ところが最近の自由化 が起こるまえの社会主義諸国は, 点線で囲ったよ うな「ねじれ」現象の形態をとっていたものと思 われる。「経済」は「先進」段階へと発展してい き，「社会」の日常生活レベルでも消費物資の多 様性はうまれてきており，一般大衆の欲求は西側 先進国なみに多様化してきていた。そうすると，

「政治」も「多元」化すれば調和し, 整合性が確 保されるのであるが，「政治」の発展は遅れ，長 い間，「一元」的な政治制度 (一党独裁制) をと ってきた。ということは「ねじれ」現象を結果す るわけで，これは不安定な状態である。したがっ て，均衡をとる方向にウェクトルは働き，整合性 を回復する力が作用するであろう。その場合, 整 合性を回復するのに二つの方向がある。一つは「社 会」の「多元」を「一元」に戻す方向であるが, これは「経済」の「先進」を「後進」へと戻すこ とを意味し, それは不可能であろう。戦争や革命 による破壊なしには，「先進」段階の「経済」を 「後進」段階に戻すことは不可能である。ひいて は「多元」的な社会生活を「一元」的な社会生活 に戻すことも不可能である。四において矢印にメ をつけた通りである。となれば,「政治」の領域 において,「一元」的な制度から「多元」的な制 度 ( 複数候補者制の選挙や複数政党制) に移行す る以外に, 均衡を回復する方法はない。点線の矢 印に示す通りである。これが1989 年末から顕 在化した社会主義国における「自由化」であり「民 主化」である。このように考えれば，社会主義諸 国における「自由化」は必然の結果であり，早晚， 顕在化してこさるをえなかった現象である。その 顕在化が１９８９年に起こるということは，おそ らく誰も予測できなかったであろうが，筆者は引 
用文献の出版年からも明らかなように，かなり早 くから，早晚この顕在化のあることを見通してき た。

社会主義諸国の自由化については，以上のよう な社会主義諸国の内部の諸条件が大きな原因であ るが，その他にも西側自由主義諸国からの影響も 無視できないであろう。社会主義諸国も今や地球 全体から孤立しては存在しえなくなっている。交 通・通信の飛躍的な発達によって，西側諸国の 「自由の風」はいやでも東側諸国に吹き込んでい く。そしていわば温室で, 西側の徴菌から曁重に 庶蔽されていた東側の苗木は, いったん温室がと り払われると，まさに「ひよわな花」で忽ちのう ちに外気にやられてしまうのである。

社会主義諸国の「自由化」には, 以上のような 西側諸国からの影響の他, ゴルバチョフという 1 オ
人のリーターの存在も無視するわけにはいかない。 しかしここではそうした面を本格的に論ずる準備 はないので, 問題点の指摘だけに留めておきたい。

\section{§「自由化」の将来}

いったん「自由化」というものを認めてしまう と, それは中途半端にとどめることはできず, 最 後まで完徹するという性質をもっている。なぜな らば，具合が悪いからといって途中でブレーキを かければ，それは「自由」に反するからである。 社会主義諸国が，長期にわたって「言論の自由」 を認めてこなかった理由はそこにある。いったん 「言論の自由」を認めると, 次の圀のように, 共 産党の一党独裁制の崩壊にまで至りつく必然性が あるからであった。言論の自由を認めれば, 選挙 における候補者も，当局のお墨つきの候補者は拒

第 5 図

言論の自由 $\rightarrow$ 複数候補者制 $\rightarrow$ 複数政党制 $\rightarrow$ 一党独裁制の崩壊

否して, 複数候補者制の選挙を要求するようにな っていく。現に社会主義諸国では，ハンガリーが 1971 年に最初の複数候補者制選挙を導入 して以来，徐々にその他の社会主義諸国にも 波及していった。しかし複数候補者制の選挙 を認めれば，いずれは複数政党制の要求へと 向っていくであろう。なぜならば, 社会には さまざまな社会階層があって，それぞれの利 害は対立することが多いからである。たとえ ばシベリアのバイカル湖は, 透明度世界一を 誇ってきたが，最近は周辺の製紙工場から排出 される公害物質で大部污染されてきている。そう すると, バイカル湖で漁業に従事している労働者 と, 製紙工場で働いている労働者とは, 同じ労働 者といっても利害は対立してくることになる。そ うすると, 共産党の政策如何によっては, 共産党 に不満な労働者は別の政党を欲してくるであろう。 複数政党制の要求は必然的にでてくる。「自由化」 の進んだ社会主義諸国の現状は，ほぼこの段階に あるといってよい。そして複数政党制を認めれば,
ある時点での選挙で共産党が負ければ, 政権を他 党に譲り渡すことになるのだから，共産主義の実 現をめざす社会主義国家ではなくなることを意味 する。つまりは社会主義国家の崩壊である。こう して, 今や社会主義諸国は,「自由化」を認めざ るをえない并証法的メカニスムから，さらに は「自由化」を認めた結果, 社会主義国家ではな くなるという弁証法的メカニスムに支配されてい るのである。

しかしそこにいくまでには, まだかなりの時間 がかかるだろうし，その期間中に妥協的な，つま りは論理の一貫しない過渡的な現象が多く発生し てくるであろう。その一つは既に現われているよ うに，ソ連国内の各共和国が独立する傾向である。 東欧諸国の自由化, あるいはソ連の制約からの独 立化をソ連が認めた ( 放任した) 以上, ソ連国内 の共和国の独立化傾向を㧕えることは, 論理的に いっても困難である。バルト三国が真先に独立を 宣言し, ソ連邦からの離脱を模索しているが, ゴ ルバチョフも経済制裁といった非論理的な手段で 
社会主義国における自由化のディレンマ

抑え込まざるをえなくなっている。しかしそれは 絶対に抑え切れるものではなく，ますます他の共 和国に波及していき，いずれはソ連邦は解体され て，それぞれの共和国が独立国家になることは明 らかである。この論理的必然性を阻止しようとい う動きも当然でてくるが, それらはすべて過渡期 の中途半端な政策ということになり，論理的にも 一貫しないという弱さを常に内蔵したものになる であろう。

\section{§ 21 世紀の課題}

20 世紀の最大の課題は, 「資本主義か社会主 義か」という選択ではなかったかと思われる。そ の課題が, 上述のような経過を辿って, 社会主義 の敗北という形で既に決着がついたわけである。 その結果，社会主義諸国も資本主義諸国に非常に 類似した社会になっていくであろう。そうなった 場合，ては次の 21 世紀の最大の課題は何になる だろうか。

筆者のみるところ，それは「東洋」と「西洋」 とのドッキング, あるいは「宗教」と「科学」と の関連づけということになるのではないかと思っ ている。資本主義も社会主義も, 科学・技術の開 発を土台としていることに変りはない。そして前 にも触れたように, 科学や技術は「前進あるのみ」 で, 逆戻りということがないから, 無限に進んで いく。そうすると, 科学や技術の無限の開発に引 張られて, 人間の欲望も無限に開発されていく。 便利な機械技術がなければ，それなりに満足して いた人間も，新しい便利な技術が与えられること によって,より高度の欲望を表出していく。たと えば, 新幹線のできる前は, 在来線の特急で結構 速いと思い，それで十分に満足していた日本人も， 新幹線ができてからは, 在来線の特急では満足で きなくなってしまっている。このように欲望の水 準は, 技術の開発によって, どんどん肥大してい くのである。

特に生命科学の領域では, 人間の生命の誕生さ えも，人工的に操作できるまでになっている。昔 であれば，子どもが出来ないのも神の恵みがない からと諦めていたし, 生れてくる赤子が男である
か女であるかも，すべて神のなせる仕業と考えら れていた。それが生命科学や医療技術の発達によ って，不婎の夫婦にも人工授精によって，子ども が与えられるようになったし, 男女の生みわけさ えも可能になっている。一昔前には, 神の領域と 考えられていたこのような分野にまて，今や人間 も立ち入ることができるようになってきた。こう して人間は, 無限に神に近づきつつある。しかし 果して, 人間が無限に神に近づき, 最後には神に とって代わることが許されるものであろうか。こ れが 21 世紀に問われる最大の難問となるであろ う。したがって, 自然科学の発達や技術の開発を このまま放任しておいていいのかどうか, という ことが問われ，そこに東洋の宗教が改めて見直さ れる機会があるように思われる。宗教は西洋にも あるし, 東洋の専有するものではないし, 科学も 西洋の専有物ではないが,「西洋の科学」と「東 洋の宗教」との関係づけが, 21 世紀の最大の課 題になるのではなかろうか。

\section{【注】}

（1）辻村明『大衆社会と社会主義社会』1967 東京大学出版会

(2) Z.Brzezinski I S.Huntington, Political Power : USA/USSR, 1963 . p. 431

(3) 辻村明「社会主義社会のタイナミスム」『ソ 連・東欧総覧』読売新聞社 1973

(4) 过村明「社会主義社会のタイナミスム」『ソ 連・東欧総覧』読売新聞社 1973

(5) W.W. Rostow, Politics and the Stoges of Growth, 1971 . p. 18 .

（6）辻村明「総論一一社会主義の運動法則に関す る試論一」『現代ソウェト社会論』（辻村明 編 ) 1970 (日本国際問題研究所)

(7) マルクス・エンゲルス「共産党宣言」『マル クス・エンゲルス全集』大月書店版 4 巻, 487 ページ

(8) レーニン「全ロシア中央執行委員会, モスク ワ・ソウェト, 労働組合合同会議での演説」

1918 .『レーニン全集』第 27 巻大月書店

(9) レーニン「校外教育第 1 回大会での講演」 1919 『レーニン全集』第 29 巻大月書店 